\title{
PENYELIDIKAN EPIDEMIOLOGI KEJADIAN COVID-19 DI WILAYAH KERJA PALABUHANRATU KABUPATEN SUKABUMI TAHUN 2020
}

\author{
${ }^{1}$ Yeni Suryamah, Kantor Kesehatan Pelabuhan Kelas II Bandung \\ yeni_suryamah@hotmail.com
}

\begin{abstract}
Abstrak
COVID-19 merupakan penyakit jenis baru yang belum pernah diidentifikasi sebelumnya pada manusia yang dapat menular dari manusia ke manusia melalui kontak erat dan droplet, tidak melalui udara. WHO telah menetapkan sebagai Kedaruratan Kesehatan Masyarakat Yang Meresahkan Dunia / Public Health Emergency of International Concern (KKMMD/PHEIC). COVID-19 pertama dilaporkan di Indonesia pada tanggal 2 Maret 2020 sejumlah 2 kasus. Sampai dengan 31 desember 2020 di Indonesia sudah terdapat 743.198 konfirmasi kasus positif, meninggal sebanyak 22.138 dan sebanyak 611.097 kasus telah dinyatakan sembuh. Kasus pandemic COVID-19 yang masuk ke Indonesia bisa dipengaruhi oleh beberapa faktor, diantaranya lemahnya pengawasan terhadap pintu masuk wilayah negara maupun kegiatan surveilans epidemiologi yang belum maksimal. Bertujuan melakukan kegiatan kekarantinaan kesehatan pada situasi khusus COVID-19 yang pelaksanaannya dilakukan di wilayah kerja Palabuhanratu Kabupaten Sukabumi. Desain studi ini menggunakan deskriptif Cross Sectional dengan batasan waktu bulan September hingga desember 2020. Alat pengumpul data menggunakan formulir pemeriksaan, Formulir PE COVID-19, Thermalgun, Spirometri dan Rapid Test COVID-19. Hasil penyelidikan epidemiologi didapatkan sebanyak 17 kapal yang datang ke Dermaga Palabuhanratu yang dikarantina $(6,16 \%)$. Pemeriksaan rapid test antibody didapatkan 45 orang dengan hasil reaktif (Reactivity rate $=0,022 \%$ ) dan 18 orang dari 45 orang reaktif tersebut diketahui positif COVID-19 (positivity rate $=0,40)$. Sebagian besar penderita COVID-19 adalah pria (89\%) dan berusia 40-49 tahun $(27,78 \%)$ yang berprofesi sebagai Mualim kapal $(44,4 \%)$. Sebanyak 4 orang dirawat di ruang isolasi RSUD Palabuhanratu, 4 orang melakukan isolasi mandiri di hotel sekitar dermaga dan sisanya melakukan karantina mandiri.Rekomendasi yaitu memperketat surveilans di pintu masuk Palabuhanratu melalui konfirmasi kepada agen kapal agar setiap kapal yang akan masuk ke area Palabuhanratu membawa hasil pemeriksaan negatif swab RTPCR atau Swab antigen.
\end{abstract}

Kata Kunci : COVID-19, karantina, penyelidikan epidemiologi

\begin{abstract}
COVID-19 is a new type of disease that has never been previously identified in humans that can be transmitted from human to human through close contact and droplets, not through the air. WHO has designated it as a Public Health Emergency of International Concern (KKMMD / PHEIC). The first COVID-19 was reported in Indonesia on March 2, 2020, with 2 cases. As of December 31, 2020 in Indonesia there have been 743,198 confirmed positive cases, 22,138 died and 611,097 cases have been declared cured. The cases of the COVID-19 pandemic that entered Indonesia can be relied on by several factors, including weak supervision of the entrance to the country's territory as well as inadequate epidemiological surveillance activities. Aiming at carrying out health quarantine activities in the special situation of COVID-19, which will be carried out at the Palabuhanratu work area, Sukabumi Regency. The design of this study uses a descriptive Cross Sectional with a time limit from September to December 2020. The data collection tools use the examination form, PE COVID-19 form, Thermalgun, Spirometry and COVID-19 Rapid Test. The results of epidemiological investigations found that 17 ships came to the Palabuhanratu Pier which are quarantined (6.16\%). The antibody rapid test showed 45 people with reactive results (level of reactivity $=0.022 \%$ ) and 18 of the 45 reactive people tested positive for COVID-19 (positive level $=0.40$ ). Most of the sufferers of COVID-19 were men (89\%) and aged 40-49 years (27.78\%) who worked as ship crews (44.4\%). A total of 4 people were treated in the isolation room of the Palabuhanratu Hospital, 4 people who are doing self-isolation at the hotel around the pier and the rest are doing self-quarantine. The recommendation is to tighten surveillance at the entrance to Palabuhanratu through confirmation to ship agents so that every ship that will enter the Palabuhanratu area brings negative RTPCR swab or antigen swab results.
\end{abstract}

Keywords : COVID-19, quarantine, epidemiological investigations 


\section{PENDAHULUAN}

Pada Desember 2019, kasus pneumonia misterius pertama kali di laporakan di Wuhan, Provinsi Hubei. Sumber penularan ini masih belum diketahui pasti. Dari kasus pertama tersebut, selanjutnya terjadi peningkatan kasus COVID-19 di China setiap hari dan memuncak diantara akhir Januari hingga awal Febuari 2020 (Susilo A, dkk, 2020). Tidak lama kemudian mulai muncul laporan dari luar Cina, pada orangorang dengan riwayat perjalanan dari Kota Wuhan dan Cina yaitu Korea Selatan, Jepang, Thailand, Amerika Serikat, Makau, Hongkong, Singapura, Malaysia dan Negara lainnya (Handayani D, 2020). WHO mengumumkan "COVID-19" sebagai nama penyakit baru ini pada 11 Februari 2020, mengikuti pedoman yang sebelumnya dikembangkan oleh Organisasi Dunia untuk Kesehatan Hewan (OIE) dan Organisasi Pangan dan Pertanian Perserikatan BangsaBangsa (FAO). (WHO,2020).

COVID-19 merupakan penyakit jenis baru yang belum pernah diidentifikasi sebelumnya pada manusia. Virus penyebab
COVID-19 ini dinamakan Sars-CoV-2. Virus corona adalah zoonosis (ditularkan antara hewan dan manusia). Penelitian menyebutkan bahwa SARS ditransmisikan dari kucing luwak (civet cats) ke manusia dan MERS dari unta ke manusia. Adapun hewan yang menjadi sumber penularan COVID-19 ini sampai saat ini masih belum diketahui. Pada tanggal 30 Januari 2020 WHO telah menetapkan sebagai Kedaruratan Kesehatan Masyarakat Yang Meresahkan Dunia / Public Health Emergency of International Concern (KKMMD/PHEIC). Penambahan jumlah kasus COVID-19 berlangsung cukup cepat dan sudah terjadi penyebaran antar Negara (Kemenkes, 2020).

Berdasarkan bukti ilmiah, COVID-19 dapat menular dari manusia ke manusia melalui kontak erat dan droplet, tidak melalui udara. Orang yang paling berisiko tertular penyakit ini adalah orang yang kontak erat dengan pasien COVID-19 termasuk yang merawat pasien COVID-19 (Kemenkes, 2020). Hal ini sesuai dengan kejadian penularan kepada petugas 
kesehatan yang merawat pasien COVID-19, disertai bukti lain penularan di luar Cina dari seorang yang datang dari Kota Shanghai, Cina ke Jerman dan diiringi penemuan hasil positif pada orang yang ditemui dalam kantor. Pada laporan kasus ini bahkan dikatakan penularan terjadi pada saat kasus indeks belum mengalami gejala (asimtomatik) atau masih dalam masa inkubasi. Laporan lain mendukung penularan antar manusia adalah laporan 9 kasus penularan langsung antar manusia di luar Cina dari kasus index ke orang kontak erat yang tidak memiliki riwayat perjalanan manapun (gralinski et all, 2020 dam Liu T et all 2020 dalam Handayani D, 2020).

COVID-19 pertama dilaporkan di Indonesia pada tanggal 2 Maret 2020 sejumlah 2 kasus. Sampai dengan 31 desember 2020 di Indonesia sudah terdapat 743.198 konfirmasi kasus positif, meninggal sebanyak 22.138 dan sebanyak 611.097 kasus telah dinyatakan sembuh (Satgas Covid-19, 2020). Situasi penyebaran COVID-19 yang sudah menjangkau seluruh wilayah provinsi di
Indonesia dengan jumlah kasus dan/atau jumlah kematian semakin meningkat dan berdampak pada aspek politik, ekonomi, sosial, budaya, pertahanan dan keamanan, serta kesejahteraan masyarakat di Indonesia. Pemerintah Indonesia telah menetapkan Keputusan Presiden Nomor 11 Tahun 2020 tentang Penetapan Kedaruratan Kesehatan Masyarakat Corona Virus Disease 2019 (COVID-19). Keputusan Presiden tersebut menetapkan COVID-19 sebagai jenis penyakit yang menimbulkan Kedaruratan Kesehatan Masyarakat (KKM) dan menetapkan KKM COVID-19 di Indonesia yang wajib dilakukan upaya penanggulangan sesuai ketentuan peraturan perundang-undangan. Penanggulangan KKM dilakukan melalui penyelenggaraan kekarantinaan kesehatan baik di pintu masuk maupun di wilayah (Kemenkes, 2020).

Kasus pandemic COVID-19 yang masuk ke Indonesia bisa dipengaruhi oleh beberapa faktor, diantaranya lemahnya pengawasan terhadap pintu masuk wilayah negara maupun kegiatan surveilans 
epidemiologi yang belum maksimal,

sehingga wabah tersebut bisa menyebar di

Indonesia. Gambar berikut merupakan alur

tatalaksana dan rujukan pada pasien terduga
Infeksi COVID-19 di pintu masuk Negara

(Kemenkes, 2020 dalam Handayani D, 2020).

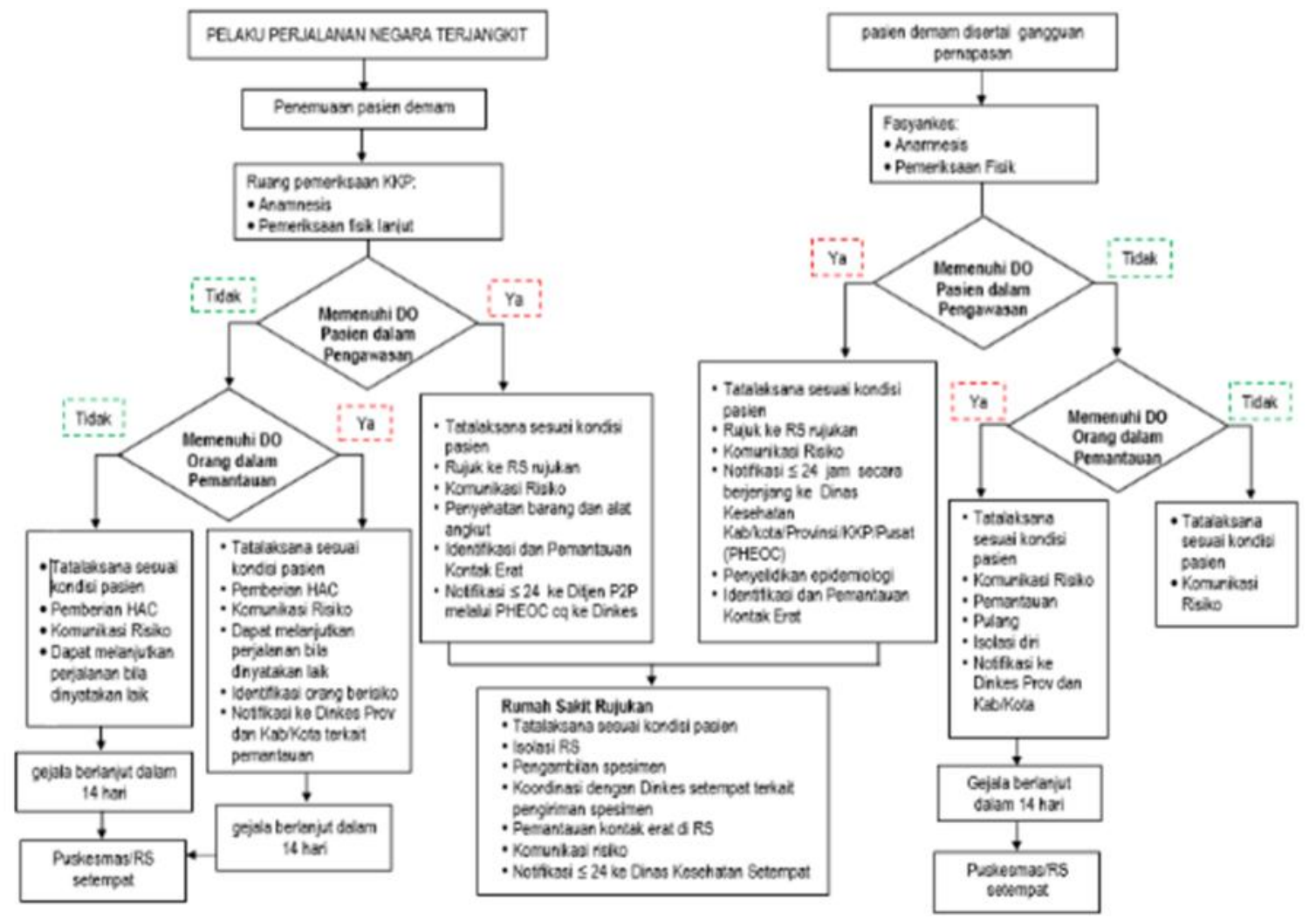

Gambar 1. alur tatalaksana dan rujukan pada pasien terduga Infeksi COVID-19

Jika di tinjau dari sistem pelayanan kesehatan Indonesia, maka peran dan kedudukan Kantor Kesehatan Pelabuhan (KKP) adalah sebagai ujung tombak sistem surveilans pelayanan kesehatan di Indonesia khususnya di pintu masuk wilayah Indonesia yang meliputi pelabuhan laut, pelabuhan udara dan lintas batas darat negara. Sebagai sarana pelayanan kesehatan terdepan di Indonesia, Kantor Kesehatan Pelabuhan memiliki tugas cegah tangkal dan keluarnya penyakit menular potensial wabah yang dapat menyebabkan kedaruratan kesehatan masyarakat yang meresahkan dunia (KKMD). Untuk itu diperlukan kegiatan kekarantinaan kesehatan pada situasi khusus COVID-19 
yang pelaksanaannya dilakukan di wilker Palabuhanratu.

\section{METODE PENELITIAN}

Desain studi ini menggunakan deskriptif Cross Sectional dengan batasan waktu bulan September hingga desember 2020 yang berada di wilayah kerja Palabuhanratu Kabupaten Sukabumi. Definisi Operasional Kasus Covid-19 adalah orang dengan hasil pemeriksaan RT PCR positif Covid-19. Populasi penelitian adalah seluruh masyarakat maupun pendatang yang berada di area perimeter Palabuhuhanratu Kabupaten Sukabumi. Sedangkan sampel merupakan sebagian masyarakat maupun pendatang yang berada di area perimeter Palabuhanratu Kabupaten Sukabumi. Alat pengumpul data menggunakan formulir pemeriksaan, Formulir PE COVID-19, Thermalgun, Spirometri dan Rapid Test COVID-19 merek Indec COVID-19 IgG/IgM. Jika pemeriksaan Rapid test menunjukan hasil reaktif, maka dilakukan pemeriksaan lanjutan berupa pengambilan swab untuk diperiksa menggunakan RT-
PCR. Pengumpulan data menggunakan data sekunder (informasi estimasi kedatangan kapal dari Agen Kapal) dan data primer (pemeriksaan kesehatan anak buah kapal dan masyarakat di area perimeter Palabuhanratu).

Proses pengolahan data analisis situasi ini meliputi tahapan sebagai berikut, yaitu:

a. Perangkat lunak untuk pengolahan data yang diperoleh diolah secara komputerisasi menggunakan program Microsoft Office

b. Analisis data sekunder dan primer berupa : Data jumlah kedatangan kapal, karakteristik ABK dan mendeskripsikan upaya yang telah dilakukan untuk pengendalian Covid19 di Palabuhanratu.

\section{HASIL DAN PEMBAHASAN}

Kegiatan kekarantinaan kesehatan dalam rangka memutus mata rantai penularan COVID-19 di wilker Palabuhanratu sudah di mulai sejak masuknya COVID-19 di Indonesia. 
Pemeriksaan dan skrining COVID-19 dilakukan pada seluruh kapal yang datang ke dermaga Palabuhanratu. Dermaga Pelabuhanratu sampai saat ini hanya melayani kapal domestic yang membawa barang/kargo berupa Batubara dan Ikan Laut.

\section{a. Penemuan Kasus di Pintu Masuk Palabuhanratu}

Kegiatan penemuan kasus di pintu masuk bertujuan untuk mengidentifikasi ada atau tidaknya kasus melalui pintu masuk negara baik melalui pelabuhan udara/laut maupun daerah perbatasan (check point). Dalam rangka implementasi International Health Regulation/IHR (2005), pelabuhan, bandara, dan Pos Lintas Batas Darat Negara (PLBDN) melakukan kegiatan karantina, pemeriksaan alat angkut, pengendalian vektor serta tindakan penyehatan. Implementasi IHR (2005) di pintu masuk negara adalah tanggung jawab Kantor Kesehatan Pelabuhan (KKP) beserta segenap instansi di pintu masuk negara. Kemampuan utama untuk pintu masuk negara sesuai amanah IHR (2005) adalah kapasitas dalam kondisi rutin dan kapasitas dalam kondisi KKMMD. Kegiatan di pintu masuk negara meliputi upaya to prevent, to detect, dan to respond terhadap COVID-19 di pelabuhan, bandar udara, dan PLBDN. Upaya tersebut dilaksanakan melalui pengawasan alat angkut, orang, barang, dan lingkungan yang datang dari wilayah/negara terjangkit COVID-19 yang dilaksanakan oleh KKP dan berkoordinasi dengan lintas sektor terkait (Kemenkes, 2020).

Kegiatan penemuan kasus COVID-19 di pintu masuk diawali dengan penemuan kasus pada pelaku perjalanan. Berikut langkah penemuan kasus di pintu masuk Palabuhanratu dengan mengacu kepada Pedoman Pencegahan dan Pengendalian COVID-19 revisi ke-5 :

- Meningkatkan pengawasan terhadap pelaku perjalanan (awak/personel) khususnya yang berasal dari wilayah dengan transmisi lokal, melalui pemeriksaan COVID-19 menggunakan rapidtest antibodi, Pemeriksaan suhu dan spirometri, pengamatan tanda dan 
gejala, dan pemeriksaan kesehatan

tambahan berupa pengukuran tekanan darah.

- Melakukan pemeriksaan dokumen kesehatan pada orang berupa validasi surat keterangan rapid test/ PCR Covid-19 yang dibawa pelaku perjalanan

- Jika ditemukan pelaku perjalanan yang terdeteksi demam melalui thermalgun maka dipisahkan dan dilakukan wawancara serta dievaluasi lebih lanjut.

- Jika ditemukan pelaku perjalanan terdeteksi demam dan menunjukkan gejala-gejala pneumonia di atas kapal berdasarkan laporan ABK, maka petugas KKP melakukan pemeriksaan dan penanganan ke atas kapal dengan menggunakan APD yang sesuai.

- Tatalaksana terhadap pelaku perjalanan dilakukan sesuai dengan kriteria kasus dan kondisi, serta prosedur penanganan kasus.

- Terhadap barang dan alat angkut dilakukan tindakan kekarantinaan sesuai SOP yang berlaku

Hasil kegiatan penemuan kasus tersebut di atas, didapatkan 17 kapal yang karantina. Jumlah kapal yang dikarantina sebagian besar ada di bulan Oktober dan Nopember. Prosentase kapal yang dikarantina selama bulan September dan Desember masih dibawah 10\% (6,16\%).

Tabel 1. Distribusi pemeriksaan COVID-19 pada ABK kapal di Palabuhanratu bulan September-Desember 2020

\begin{tabular}{|l|c|c|c|c|}
\hline \multirow{2}{*}{ Bulan } & \multicolumn{3}{|c|}{ Kapal yang diperiksa } & \multirow{2}{*}{ \% Karantina } \\
\cline { 2 - 4 } & karantina & Bebas karantina & Jumlah & \\
\hline September & 1 & 11 & 12 & $8.33 \%$ \\
\hline Oktober & 7 & 90 & 97 & $7.22 \%$ \\
\hline Nopember & 5 & 100 & 105 & $4.76 \%$ \\
\hline Desember & 4 & 58 & 62 & $6.45 \%$ \\
\hline TOTAL & 17 & 259 & 276 & $6.16 \%$ \\
\hline
\end{tabular}

Sebagian besar kapal yang dikarantina merupakan kapal yang datang dari pelabuhan muat Palembang (12 Kapal). Sementara kedatangan kapal dari Jambi dan tarahan hanya sebesar 2 kapal. 


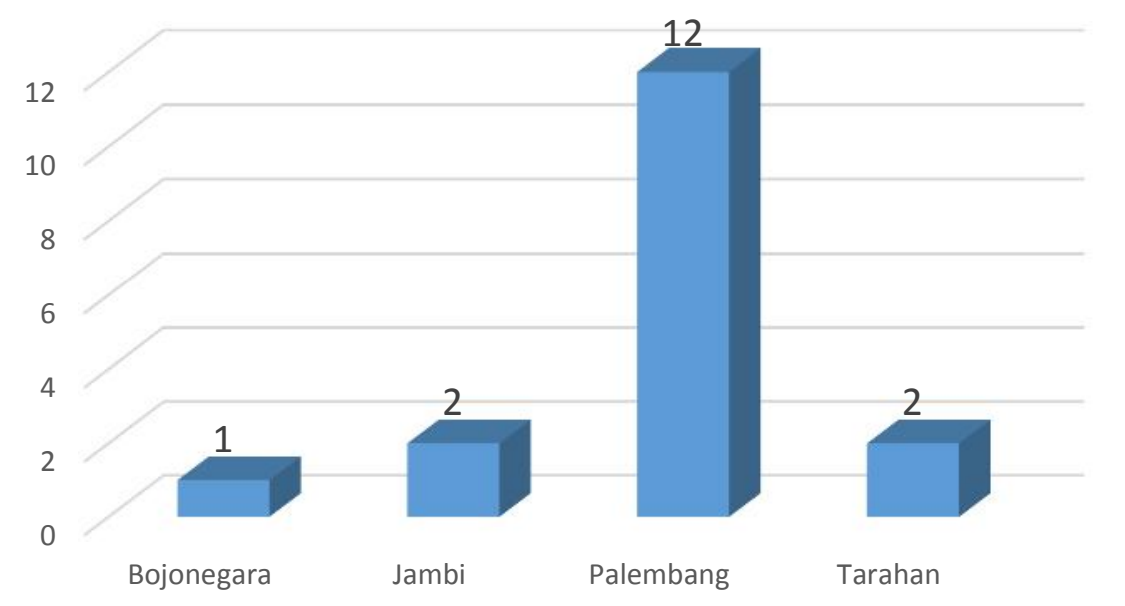

Grafik 1. Distribusi Kedatangan Kapal yang di karantina di Palabuhanratu

Tabel 2. Distribusi kedatangan kapal yang dikarantina berdasarkan waktu di Palabuhanratu

\begin{tabular}{|l|c|c|c|c|c|}
\hline \multirow{2}{*}{ Bulan } & \multicolumn{4}{|c|}{ Jumlah Kedatangan Kapal } & \multirow{2}{*}{ TOTAL } \\
\cline { 2 - 5 } & Bojonegara & Jambi & Palembang & Tarahan & \\
\hline September & & & 1 & & 1 \\
\hline Oktober & & & 7 & & 7 \\
\hline Nopember & 1 & & 3 & 1 & 5 \\
\hline Desember & & 2 & 1 & 1 & 4 \\
\hline TOTAL & 1 & 2 & 12 & 2 & 17 \\
\hline
\end{tabular}

Berdasarkan tabel 2 tersebut diketahui bahwa jumlah kedatangan kapal yang di karantina terbanyak terdapat pada bulan Oktober yang berasal dari Palembang yaitu sebanyak 7 kapal. Pada bulan tersebut diketahui bahwa Palembang merupakan salah satu kota zona merah COVID-19.

Selanjutnya dilaukan upaya pengendalian untuk kapal tersebut yaitu :

1. Pemasangan bendera Kuning pada Kapal

2. Kapal agar tetap berada di wilayah tengah pantai (outbar)

3. Tidak diterbitkannya COP (Certificate of Pratique)/ Sertifikat Bebas karantina

4. Melakukan anamnesa dan isolasi mandiri pada ABK reaktif COVID-19
Adapun rekomendasi yang diberikan kepada kapal tersebut adalah :

1. Melakukan swab secara mandiri dengan dikoordinir oleh owner/Agen yang bersangkutan, KKP Bandung Wilker Palabuhanratu hanya memfasilitasi dan menjadi narahubung kegiatan pengambilan swab

2. Tidak direkomendasikan untuk bongkar muat kapal

3. Tidak melakukan kontak fisik dengan ABK lain (Isolasi ABK Reaktif)

4. Pemantauan kondisi kesehatan ABK reaktif setiap hari

5. Seluruh ABK diwajibkan memakai masker dan Cuci Tangan Pakai Sabun (CTPS) 
Selain itu KKP Bandung Wilker Palabuhanratu segera melakukan koordinasi dengan lintas sector dan lintas program untuk menindaklanjuti temuan tersebut. Pihak owner kapal menyetujui untuk menanggung seluruh biaya pemeriksaan swab RT-PCR seluruh ABK reaktif tadi dengan narahubung Agen kapal tersebut. KKP Bandung Wilker palabuhanratu juga melakukan mediasi dengan Labkesda Kota Sukabumi dan Labkesda Kabupaten Sukabumi untuk melakukan pengambilan swab pada $\mathrm{ABK}$ tersebut di atas kapal dibantu oleh tim KKP Bandung Wilker Palabuhanratu.

\section{b. Karakteristik Responden}

Pemeriksaan rapid test antibodi dilaksanakan di area Buffer wilker Palabuhanratu yang sebagian besar merupakan Anak Buah Kapal Batubara dan nelayan serta masyarakat di sekitar dermaga Palabuhanratu.

Tabel 3. Distribusi hasil pemeriksaan COVID-19 pada ABK dan Masyarakat di Area Palabuhanratu bulan September-Desember 2020

\begin{tabular}{|l|r|r|r|r|r|r|r|}
\hline \multirow{2}{*}{ Bulan } & \multicolumn{3}{|c|}{ Hasil Rapid Test Antibodi } & \multicolumn{2}{c|}{ Hasil Swab RT-PCR } & \multirow{2}{*}{$\begin{array}{c}\text { Positivity } \\
\text { rate }\end{array}$} \\
\cline { 2 - 8 } & Reaktif & Non reaktif & Jumlah & Positif & Negatif & Jumlah & \multicolumn{1}{c}{0.75} \\
\hline September & 4 & 508 & 512 & 3 & 1 & 4 & 0.08 \\
\hline Oktober & 12 & 531 & 543 & 1 & 11 & 12 & 0.46 \\
\hline Nopember & 26 & 650 & 676 & 12 & 14 & 26 & 0.67 \\
\hline Desember & 3 & 351 & 354 & 2 & 1 & 3 & 0.40 \\
\hline TOTAL & 45 & 2040 & 2085 & 18 & 27 & 45 & \\
\hline
\end{tabular}

Selama bulan September-Desember telah dilakukan pemeriksaan rapid test sebanyak 2.085 dan didapatkan hasil pemeriksaan reaktif sebanyak 45 orang (Reactivity rate sebesar 0,022). Dari ke 45 orang yang dinyatakan reaktif kemudian dilakukan pengujian lanjutan melalui pengambilan lendir tenggorokan dengan cara swab untuk diperiksa di Laboratorium menggunakan metode RT-PCR. Hasil RTPCR didapatkan 18 orang dinyatakan positif COVID-19 dengan positivity rate mencapai 0,40. Hal ini menunjukan bahwa rapid test menggunakan merek Indec COVID-19 IgG/IgM mampu menjaring sebanyak $40 \%$ pasien COVID-19. 
Tabel 4. Hasil Pemeriksaan Oximeter dan Suhu tubuh pada ABK dan masyarakat Reaktif Rapid test Antibodi di Area Palabuhanratu bulan September-Desember 2020

\begin{tabular}{|l|c|c|c|c|c|c|}
\hline $\begin{array}{c}\text { Pemeriksaan } \\
\text { Kesehatan }\end{array}$ & $\mathrm{N}$ & median & rata2 & modus & $\min$ & $\max$ \\
\hline Oximeter SP02 & 45 & 97.00 & 97.22 & 98.00 & 95.00 & 99.00 \\
\hline Suhu $\left({ }^{\circ} \mathrm{C}\right)$ & 45 & 36.40 & 36.25 & 36.50 & 35.50 & 36.70 \\
\hline
\end{tabular}

Dari 45 orang dengan hasil reaktif pada rapid test antibody diketahui rata-rata suhu tubuh masih dalam batas normal yaitu $36.25^{\circ} \mathrm{C}$ (masih dibawah $37^{\circ} \mathrm{C}$ ) dengan minimal $35.50^{\circ} \mathrm{C}$ dan maksimal $36.70^{\circ} \mathrm{C}$. sementara hasil pemeriksaan oximeter secara keseluruhan masih dalam batas normal dengan rata-rata sebesar 97.22 dan minimal 95,00 maksimal 99,00.

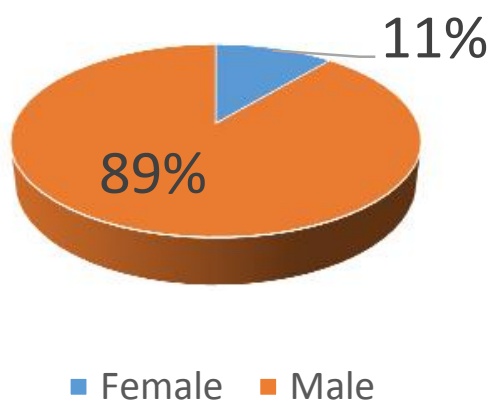

Grafik 2. Distribusi Penderita COVID-19 berdasarkan Jenis kelamin di Area Palabuhanratu

Dari 18 orang yang dinyatakan positif COVID-19 diketahui proporsi Pria penderita COVID-19 (89\%) lebih besar dibandingkan dengan wanita (11\%). Sementara bila dilihat dari kelompok umur, sebagian besar penderita COVID-19 berusia 20-29 tahun $(44,44 \%)$ dan usia 40 49 tahun $(27,78 \%)$ serta usia 50-59 tahun $(22,22 \%)$. Sebagian besar penderita Covid19 ini tidak mempunyai gejala apapun ataupun komorbid lainnya.

Tabel 5. Distribusi Penderita COVID-19 berdasarkan kelompok umur di Area Palabuhanratu

\begin{tabular}{|c|r|r|}
\hline USIA & JUMLAH & Persentase \\
\hline 20-29 Tahun & 8 & 44.44 \\
\hline 30-39 Tahun & 1 & 5.56 \\
\hline 40-49 Tahun & 5 & 27.78 \\
\hline 50-59 Tahun & 4 & 22.22 \\
\hline JUMLAH & 18 & 100.00 \\
\hline
\end{tabular}

Sebagian besar penderita COVID-19 ini merupakan Mualim Kapal (8 orang) dan ASN (4 orang) yang merupakan pegawai di salah satu kantor pemerintah pusat yang berada di area perimeter Palabuhanratu. Sementara para ABK kapal penderita COVID-19 tersebut mengaku turun ke darat untuk membeli kebutuhan sehari-hari di pasar, sebelum berlayar ke Palabuhanratu. 


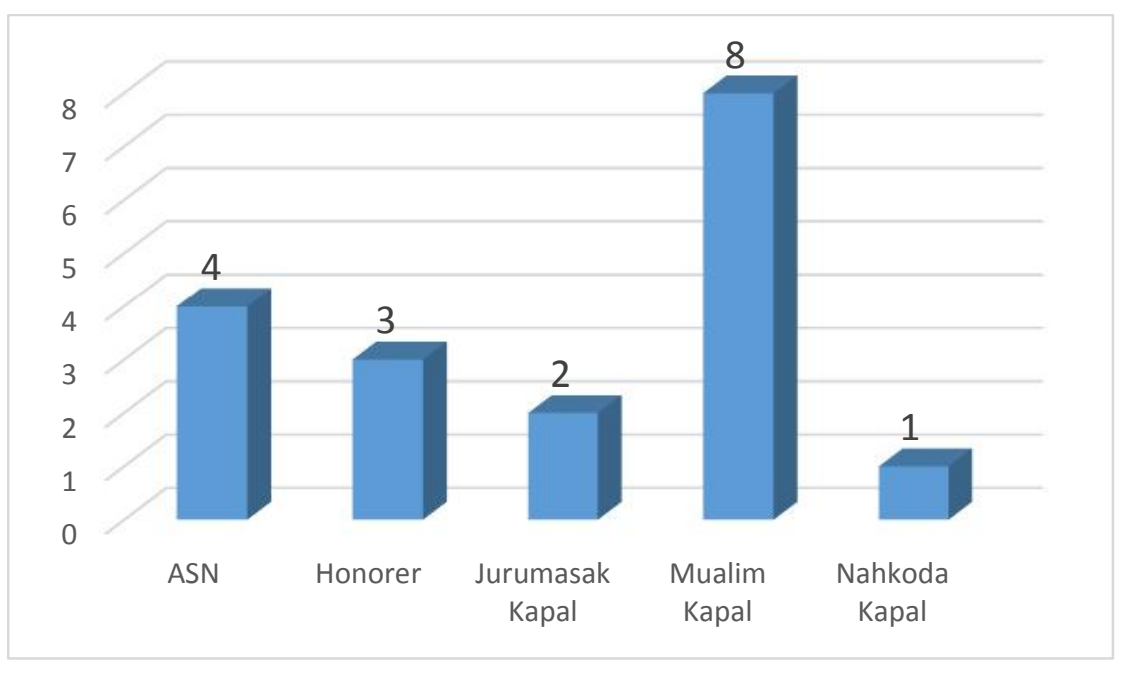

Grafik 3. Distribusi penderita COVID-19 berdasarkan Pekerjaan di Area Palabuhanratu

Sebagian besar penderita Covid-19 yang ditemukan di area Palabuhanratu tidak ditemukan gejala klinis Covid-19. Hanya ada satu orang yang mengalami gejala pilek, sakit tenggorokan dan sakit kepala. Seperti terlihat pada table 6 .

Tabel 6. Distribusi gejala klinis Covid-19 penderita di area Palabuhanratu

\begin{tabular}{|l|l|c|c|}
\hline No & Gejala dan Tanda & Ya & Tidak \\
\hline 1 & Demam & 0 & 18 \\
\hline 2 & Batuk & 0 & 18 \\
\hline 3 & Pilek & 1 & 17 \\
\hline 4 & Sakit Tenggorokan & 1 & 17 \\
\hline 5 & Sesak Napas & 0 & 18 \\
\hline 6 & Menggigil & 0 & 18 \\
\hline 7 & Sakit kepala & 1 & 17 \\
\hline 8 & Lemah & 0 & 18 \\
\hline 9 & Nyeri Otot & 0 & 18 \\
\hline 10 & Mual atau Muntah & 0 & 18 \\
\hline 11 & Nyeri Abdomen & 0 & 18 \\
\hline 12 & Diare & 0 & 18 \\
\hline
\end{tabular}

Tabel 7. Distribusi Faktor Kontak/Paparan 14 hari sebelum sakit di area Palabuhanratu

\begin{tabular}{|l|l|c|c|}
\hline No & \multicolumn{1}{|c|}{ Gejala dan Tanda } & Ya & Tidak \\
\hline 1 & Memiliki riwayat perjalanan & 0 & 18 \\
\hline 2 & Memiliki kontak erat dengan kasus suspek & 1 & 17 \\
\hline 3 & Memiliki kontak erat dengan kasus konfirmasi & & \\
\hline 4 & Mengunjungi pasar hewan & 2 & 18 \\
\hline 5 & $\begin{array}{l}\text { Memiliki riwayat berkunjung ke faskes (sebagai } \\
\text { pasien, pekerja, pengunjung) }\end{array}$ & 0 & 18 \\
\hline 6 & Termasuk cluster ISPA berat & 0 & 18 \\
\hline
\end{tabular}


Hasil wawancara diketahui bahwa penderita sebelum dinyatakan sakit hanya ada 1 orang yang memiliki kontak erat dengan kasus suspek dan 2 orang pernah mengunjungi pasar hewan dalam 14 hari terakhir.

\section{c. Rujukan dan Isolasi Penderita \\ Covid-19}

Menurut Pasal 63 UU nomor 6 Tahun 2018 menyebutkan bahwa karantina wilayah sebagai bagian respon dari kedaruratan kesehatan masyarakat yang bisa dilaksanakan kepada seluruh masyarakat di suatu wilayah apabila hasil konfirmasi laboratorium sudah terjadi penyebaran penyakit antar anggota masyarakat di wilayah tertentu.

Dari 18 orang yang dinyatakan positif COVID-19 tersebut, sebanyak 4 orang dirawat di ruang isolasi RSUD Palabuhanratu, 4 orang melakukan isolasi mandiri di hotel sekitar dermaga dan sisanya di jemput pihak owner kapal untuk dilakukan karantina mandiri. Hal ini disebabkan karena di wilker Palabuhanratu belum tersedianya lokasi karantina.

Sebelum evakuasi penderita COVID19 dilaksanakan, KKP Bandung wilker palabuhanratu melakukan koordinasi lanjutan dengan Sekretaris Daerah Kab. Sukabumi, RSUD Palabuhanratu, Kantor Unit Penyelenggara Pelabuhan Kelas III Palabuhanratu, Syahbandar, Satuan Polisi Air, Camat Palabuhanratu, Puskesmas
Palabuhanratu, Owner dan Agen kapal agar proses evakuasi tersebut berjalan lancar.

Pada proses evakuasi tersebut, terdapat kendala angkutan laut yang akan mengantarkan ABK Positif COVID-19 ke dermaga dan adanya protes dari warga sekitar dermaga dengan adanya evakuasi tersebut. Namun berkat pendekatan persuasif kepada masyarakat sekitar oleh KKP Bandung Wilker Palabuhanratu dan rekomendasi PPNP (Pelabuhan Perikanan Nusantara Palabuhanratu) untuk mengkosongkan dermaga dari kapal sandar akhirnya bisa diterima masyarakat sekitar. Kesigapan Satuan Polisi Air (Satpolair) dalam evakuasi ABK dari Kapal Batubara tersebut ke dermaga memudahkan proses evakuasi tersebut.

Hal ini diterangkan pada pasal 54 UU nomor 6 Tahun 2018 terkait kewajiban pemerintah dan masyarakat selama karantina wilayah berlangsung, seperti pejabat yang melakukan karantina kesehatan wajib memberikan penjelasan kepada masyarakat sebelum menerapkan kebijakan karantina wilayah.

\section{SIMPULAN}

- Selama bulan September-Desember 2020 didapatkan 17 kapal yang datang ke Dermaga Palabuhanratu yang dikarantina $(6,16 \%)$.

- Hasil pemeriksaan rapid test antibody didapatkan 45 orang dengan hasil reaktif 
(Reactivity rate $=0,022 \%$ ) dan 18 orang dari 45 orang reaktif tersebut diketahui positif COVID-19 (positivity rate = $0,40)$.

- Sebagian besar penderita COVID-19 adalah pria (89\%) dan berusia 40-49 tahun $(27,78 \%)$ yang berprofesi sebagai Mualim kapal (44,4\%).

- Sebanyak 4 orang dirawat di ruang isolasi RSUD Palabuhanratu, 4 orang melakukan isolasi mandiri di hotel sekitar dermaga dan sisanya melakukan karantina mandiri.

\section{REKOMENDASI}

- memperketat surveilans di pintu masuk Palabuhanratu melalui konfirmasi kepada agen kapal agar setiap kapal yang akan masuk ke area Palabuhanratu membawa hasil pemeriksaan negatif swab RT-PCR atau Swab antigen.

- Penguatan koordinasi dengan lintas sektor dan lintas program serta stake holder terkait di wilker Palabuhanratu

\section{REFERENSI}

Handayani D, dkk (2020), Penyakit Virus Corona 2019, Jurnal Resporologi Indonesia, Volume 40, Nomor 2, April 2020.

Kemenkes (2020), Pedoman dan Pencegahan Pengendalian

Coronavirus Disease (COVID-19) Revisi ke-5

Keputusan Presiden Nomor 11 Tahun 2020 tentang Penetapan Kedaruratan Kesehatan Masyarakat Corona Virus Disease 2019 (COVID-19)

Satgas Covid-19, 2020, Data kumulatif Kasus Covid 19, https://covid19.go.id/

Susilo A, dkk (2020), Coronavirus Disease 2019 : Tinjauan Literatur Terkini, Jurnal Penyakit DalamIndonesia, Vol 7 no.1, Maret 2020.

Undang Undang Nomor 6 Tahun 2018, Karantina Kesehatan

World Health Organization. (2020), Naming the coronavirus disease (COVID-19) and the virus that causes it [Internet]. Geneva: World Health Organization; 2020 [cited 2020 March 29]. Available from: https://www.who.int/emergencies/dis eases/novelcoronavirus-

2019/technical-guidance/naming-thecoronavirusdisease-(covid-2019)and-the-virus-that-causes-it. 